\title{
DISCOURSE OF EARLY MIGRATION TO THE MASSACHUSETTS BAY COLONY
}

The migration to the Massachusetts Bay Colony had crucial consequences for the seventeenth century England and her colonies. It provided momentum for the Great Migration on the eve of the English Civil Wars of the 1640s, it preconditioned the advance of theocracy and local exceptionalism in Massachusetts, and finally, it fostered the development of 'New England Puritanism', which influenced the both sides of Atlantic. However, these impressive outcomes could not be known at the very start of emigration to Massachusetts in 1628-1631. Did English men and women ever notice this migration? Was it seen as something exceptional? Did it have any impact on domestic issues in England? Relying on promotional literature, sermons, and correspondence, this paper places migration to Massachusetts within transatlantic context of the early Stuart period and explores the views of its participants and observers. It argues that migration to Massachusetts between 1628 and 1631 was never regarded as an exceptional opportunity. Although mobility was not uncommon for English society, its discourse generally favoured other destinations such as Ireland, the Netherlands or the West Indies. Even the 'godly' regarded Massachusetts as just one of the suitable settlements and stressed its unexceptional nature. However, the paper outlines two crucial impacts, the discourse of early Massachusetts migration did have on the English society. First, it improved public perception of potential emigrants by upgrading their image from the 'idle drones' of John Smith to the respectful 'godly'. Secondly, it introduced contemporary religious controversy into the discussions of migration to America, thus setting the discourse of Reformation in transatlantic perspective. Refs 50.

Keywords: New England, Great migration, Atlantic world, early modern England, exceptionalism, colonisation, puritans, godly, John Winthrop, Smith, English Reformation, America.

For citation: Adamova N. E., Shershneva S. V. Discourse of early migration to the Massachusetts bay colony. Vestnik of Saint Petersburg University. History, 2017, vol. 62, issue 4, pp. 839-854. https:// doi.org/10.21638/11701/spbu02.2017.411

\section{Н.Э. Адамова, С. В. Шеринева}

\section{НАЧАЛО ЭМИГРАЦИИ В КОЛОНИЮ МАССАЧУСЕТС В ПРЕДСТАВЛЕНИЯХ АНГЛИЙСКОГО ОБЩЕСТВА}

В долгосрочной перспективе английская эмиграция в колонию Массачусетского залива в 1630-е годы стала одним из ключевых событий английской и колониальной истории XVII в. Она положила начало «Великому переселению» из Англии накануне гражданских войн, утвердила теократический режим в Массачусетсе, развив представления об «исключительности» у его жителей, наконец, обусловила становление особого, «новоанглийского пуританизма», который оказал значительное влияние на английские территории по обе стороны Атлантического океана. Однако эти впечатляющие последствия, естественно, не могли быть извест-

Adamova Nina Eduardovna - PhD in History, Senior Lecturer, St. Petersburg State University, 7-9, Universitetskaya nab., St. Petersburg, 199034, Russian Federation; n.adamova@spbu.ru

Shershneva Svetlana Vladimirovna - PhD in History, Associate Professor, St. Petersburg State University, 7-9, Universitetskaya nab., St. Petersburg, 199034, Russian Federation; shershneva@spbu.ru

Адамова Нина Эдуардовна - кандидат исторических наук, ст. преподаватель, Санкт-Петербургский государственный университет, Российская Федерация, 199034, Санкт-Петербург, Университетская наб., 7-9; n.adamova@spbu.ru

Шершнева Светлана Владимировна - кандидат исторических наук, доцент, Санкт-Петербургский государственный университет, Российская Федерация, 199034, Санкт-Петербург, Университетская наб., 7-9; s.shershneva@spbu.ru

The article was prepared within the grant of the President of Russian Federation to support young Russian scholars, MK-3624.2017.6 ("Theory and practice of revolution in the context of the development of parliamentary monarchy in Great Britain in XVII-XIX ${ }^{\text {th }}$ centuries").

(c) Санкт-Петербургский государственный университет, 2017 
ны в самом начале эмиграции в Массачусетс - в 1628-1631 гг. Обратили ли жители Англии внимание на первые отъезды соотечественников в Массачусетс? Представлялась ли им эта эмиграция чем-то необычным или исключительным? Оказали ли сведения о переселении какое-либо воздействие на английское общество? На основе рекламных материалов, проповедей и корреспонденции в статье предпринимается попытка рассмотреть эмиграцию в Массачусетс в трансатлантическом контексте раннестюартовской эпохи и проанализировать мнения ее участников и наблюдателей. В статье утверждается, что в 1628-1631 гг. переселение в Массачусетс не казалось многообещающим. Хотя внутренняя миграция и заморская эмиграция не были чужды англичанам, общественное мнение более высоко ценило другие направления Ирландию, Нидерланды или Вест-Индию. Даже пуритане считали Массачусетс лишь одним из проектов пуританских поселений, и не самым перспективным. Вместе с тем в статье выделяются и два последствия дискуссий об эмиграции в Массачусетс. Во-первых, образ потенциального эмигранта стал более привлекательным: пропагандистская литература превратила его из «ленивого трутня» в уважаемого и благочестивого переселенца. Во-вторых, и сторонники, и противники эмиграции в Массачусетс в своей полемике неразрывно связали это переселение с бушевавшими в Англии религиозными противоречиями и тем самым поместили английскую Реформацию в трансатлантическую перспективу. Библиогр. 50 назв.

Ключевые слова: Новая Англия, Великое переселение, атлантический мир, раннестюартовская Англия, Уинтроп, Реформация, пуритане, исключительность, колонизация, американские колонии.

If any such as are knowne to be Godly and liue in wealth and prosperity here shall forsake all this, to ioyn themselues with this Church and to runne an Hazard with them of an hard and meane condition, it will be an example of great vse for ... remouing the scandall of worldly and sinister respects which is cast upon the Adventurers...

John Winthrop, 1629 [Winthrop 1931b, p. 140]

The founding of the Massachusetts Bay colony in 1628-1631 has been considered by many historians as a turning point in the early history of the English colonial America, being significant for both the British and American history. Indeed, migration to Massachusetts heralded the beginning of the 'Great migration' of the 1630s (a 'Puritan' exodus or hegira) ${ }^{1}$, when some 20,000 Englishmen moved to the New England colonies. The Great Migration indicated the impending crisis in the English society, which eventually culminated in the Civil Wars of the 1640s. In terms of American history, the migration of 1628-1631 has been even more greatly valued. For many decades, historiography has viewed Massachusetts as the birthplace of the virtues, which laid the foundation for the American spirit identity and fostered beliefs in 'American exceptionalism'. In a word, national historical narratives tended to praise this migration as a foundational myth and, as a consequence, to overestimate its actual significance for the early seventeenth century. But did the early emigration to Massachusetts seem significant to contemporary English men and women? Did it attract their attention? How did the leadership of migration, the 'godly' in England, their adversaries and critics estimate emigration? Was it taken as a mission, exodus, or exile? Did the discourse of migration to Massachusetts between 1628 and 1631 influence English society and if so, how?

${ }^{1}$ The recent research has questioned the assumption that the Great migration was 'Puritan' [Cressy 2007, p. 87-89]. 
To narrow the scope of research, we have to consider three major interrelated topics within the early modern discourse of any overseas enterprise ${ }^{2}$ : (1) discourse of colonisation (discussions of the lawfulness of possessing lands and their advantages for the English kingdom); (2) discourse of the overseas territories (geographical and historical descriptions and the image of the land); and (3) discourse of emigration (attitudes to the lawfulness of coming over and leaving the native land). With respect to the Massachusetts colony, the history of the first two topics has been thoroughly researched, while the third one - the question of contemporary discourse of migration and its perception in England - still requires examination, especially in the transatlantic context ${ }^{3}$. This paper will rely upon synchronic sources produced between 1628 and $1631^{4}$ to explore the attitudes to the early migration to Massachusetts in the context of transatlantic economic, social and religious circumstances of the time ${ }^{5}$.

\section{English discourse of mobility}

By the 1620s, the English men and women had some knowledge and experience of migration. Its most common type was a domestic mobility. The research of the last four decades, however controversial, generally has demonstrated that the English society was fairly mobile in the sixteenth and seventeenth centuries. People moved within their counties, migrated to the urban areas, and many of them travelled or moved to London. Apprenticeship, marriages, domestic service, seasonal jobs urged people to change their place of living; sometimes people were driven by economic fluctuations, decline in crafts in the local area, or plague [Thompson 1994, p. 5].

The question of the discourse of domestic mobility is rather complicated. Some historians claimed that Englishmen accepted mobility as a "commonplace" [Rich 1950, p. 262]. Others, relying upon more accurate estimation of the sources, asserted that migration did coexist with "the localism, rootedness, and custom", which were the norm for respectful Englishmen [Thompson 1994, p. 224]. Nevertheless, the scholars agree that domestic migration, however short-termed or short-distanced, was typical [Whyte 2000, p. 173], and no evidence demonstrates that it was frowned upon. The concept of migrants and migration must have been familiar especially to those dwelling in the southeastern counties, side by side with European immigrants - mostly Dutchmen, but also French, Burgundian and the others [Rich 1950, p. 262-263]. As to the attitude to declassed elements such as vagabonds, they were generally held in low regard in England and usually blamed for all kinds of troubles in the realm ${ }^{6}$.

${ }^{2}$ By 'discourse of migration to Massachusetts' the paper means the complex of public discussions, opinions, reactions, sentiments, and attitudes relating to migration to Massachusetts.

3 The lack of research in this area has been acknowledged, see: [Bremer, Botelho 2005, p. 8, 15-17].

${ }^{4}$ Extant sources were produced to a large degree by colonial leadership or ministry. It is much more difficult to trace the opinions of ordinary colonists. Some insights about their motivation can be gained from the brilliant studies, based on exploration the entries in the port passenger registers ([Games 2001; Breen, Foster 1973; Anderson 1985]) and an ambitious project The Great migration [Anderson 2012].

5 The transatlantic approach has been developing since the 1970s. Its essence is the idea that the European countries and the territories of European expansion comprised a sole interrelated organism. See: [Bailyn 2005, p. 3-56].

${ }^{6}$ However, only a small proportion of vagabonds was actually examined for crimes [Whyte 2000, p.52]. 
Although English mobility was predominantly domestic, a considerable number of people chose to emigrate overseas [Whyte 2000, p. 173]. In the pre-Civil War period, the most typical place to move to was Ireland. Having been promoted by the English government since the 1580s, migration to Ireland had involved at least 100,000 people from England, Wales and Scotland until 1641 [Oxford History 2001, p. 139-140] ${ }^{7}$. Protestant regions of Ireland attracted various English colonists, both economically and religiously. For example, the uncles of John Winthrop, the future Governor of Massachusetts, owned estates in Ireland; John Winthrop himself was contemplating migrating to Ireland in the early 1620s [Bremer 2003, p. 139-140]. Ireland also attracted English nonconformists of various sorts, from Scottish Presbyterians, to Puritans, to Separatists ${ }^{8}$.

Another common destination for emigrants was continental Europe, primarily the Netherlands and German states, and it had remained popular through the 1630s ${ }^{9}$. English merchants, weavers, and other artisans found better income in Holland [Breen, Foster 1973, p. 221]. Also, this country traditionally attracted various English religious nonconformists and exiles. It had maintained its status as a universal refuge at least until 1633, when under the Stuart pressure the Netherlands had 'to crack down' on the local English 'Puritans' [Bremer 1995, p. 46]. In addition to these diverse economic and religious reasons, the Thirty Years' War also attracted many settlers to Europe [Games 2001, p. 25-26]. Some were recruited into the continental Protestant armies for money, and others, like the 'godly', for political and religious reasons [Bremer 1994, p. 66-71].

The attitudes to the overseas emigration were rather diverse. English authorities were alarmed at the loss of craftsmen moving to Netherlands. For example, in 1632 the bishop Matthew Wren even suspected that the Dutch were attracting craftsmen on purpose, in order to drain the English economy [Breen, Foster 1973, p. 206]. James I and Charles I attempted to regulate and curtail the flow overseas in order to assert their authority over uncontrolled ventures and to prevent depopulation ${ }^{10}$. Public perception of migration to Ireland or the Continent varied. For example, Separatist refugees were generally detested for their open 'separation' from the Church of England, which the authorities labelled as a treason and even radical nonconformists regarded as a schism and a sin; but the English soldiers were praised for their attempts to defend 'true religion' - in both sermons and popular ballads. Thus, by the 1630s, Ireland and the Continent were seen as the most attractive destinations for emigration, for whatever reason.

The founding of the American colonies opened a new destination for English emigrants. By the 1630s, the English permanent settlements across the Atlantic Ocean included only Virginia, several West Indies islands, and a tiny New Plymouth ${ }^{11}$. However, most of them were not regarded as suitable places for permanent settlement. The largest colony,

7 To compare, there were only about 6,000 settlers in Massachusetts by 1636 and 8,000 in Virginia by 1640 [Oxford History, 2001, p. 140].

${ }^{8}$ Presbyterians and puritans were even incorporated in the Church of Ireland. This relative 'flexibility' had lasted only until 1634-1636, when nonconformist elements were excluded from the Church [Puritans 2006, p. 432-434].

9 For example, in 1635, out of 7,507 passengers, registered at London port, 2,629 travelled to the Continent, either to their places of residence or to serve as soldiers [Games 2001, p. 21].

${ }^{10}$ In 1630, Charles' proclamation appointed commissioners to administer an oath to all people leaving England, and to register their personal details [Games 2001, p. 17-18].

11 There were other colonial projects as well, among them the attempts to establish settlements in New England and in New Scotland [Akimov 2002]. 
Virginia, had a dubious reputation, mostly because of famine and cases of cannibalism in 1609-1610, the 'massacre' of 1622 and the losses these catastrophes inflicted [Oxford History 2001, p. 73]. The territory of New England had also been infamous for the failure of numerous attempts to settle permanent colonies there [Cressy 2007, p. 3-4]. The newly established West Indies colonies (St Christopher, Barbados, Nevis) were spared from such misfortunes and therefore attracted most of emigrants to the Americas [Oxford History 2001, p. 221] (involving, for example, members of the Winthrop family) ${ }^{12}$. Still, in 1625, only about 2,000 Englishmen lived in American colonies [Greene, Hurrington 2006, p.3] and actual migration to America was much smaller than to Ireland or the Continent. These circumstances may have framed the discourse of migration to America in the 1620s: doubts in the success and security of the colonies and the specific image of a potential migrant.

Contemporary promotion literature tried to stress the importance of Elizabethan and early Stuart explorations. Richard Hakluyt, Samuel Purchas, John Smith, and many others published meticulous descriptions of American lands and details of English voyages to America, aiming to persuade the English Monarchs, investors and colonists to become involved in colonial enterprises [Hakluyt 1877, Purchas 1614, Smith 1616]. However, the expectations of colonisation voiced by these authors did not reflect the reality of the $1620 \mathrm{~s}^{13}$, and it is debatable if common people beyond the narrow circle of explorers and adventurers knew of these books ${ }^{14}$ and, if they did know them, were influenced more than by the rumours of disasters in Virginia or New England. Thus, in spite of colourful promotional literature, the American migration was not perceived as a bright opportunity for those Englishmen, who looked for a permanent migration of the whole families [Cressy 2007, p. 37]. However, in case of short-term migrations, America could be viewed more positively, just as one of the choices facing a young male: he could move either to a bigger city, or to London, or to the Continent as a soldier, or probably to the West Indies - all having the same reasons to migrate ${ }^{15}$.

The image of a potential emigrant to America was not very appealing. Promotional tracts usually depicted one suitable for emigration as an idle person hampering England's well-being merely by his/her presence. Such an 'idleness' was attributed primarily to the poor. This point of view stemmed from the widely accepted conviction of the $1620 \mathrm{~s}$ that England's wealth suffered from overpopulation and idleness of the unemployed ${ }^{16}$. Sending poor to the colonies would be "benefitiall to the Common-wealth", as explorer

12 A son of John Winthrop, Henry, lived at Barbados for a while. Winthrop's another son, John, travelled there. [Winthrop papers 1931, p.v-vii]. Aristocratic entrepreneurs were also interested in the West Indies. The Earl of Warwick with a group of prominent Puritan grandees would establish the 'godly' colony Providence Island in 1630 [Kupperman 1993].

13 Alison Games rightfully called the time until the 1620 s an 'imaginative period of colonisation' [Games 2001, p. 4-5, 214].

${ }^{14}$ Nicholas Canny provides an example of Adam Winthrop, father of John Winthrop, who used to make regular entries to his diary on the major events, but never mentioned American colonisation [Oxford History 2001, p. 5]. Another example: a migrant of 1630, Roger Clap, later recalled, "I never so much as heard of New England until I heard of many godly Persons that were going there". Quoted from: [Anderson 1985, p. 378].

15 There is an opinion that migration to America was a mere extension of domestic urban-rural mobility [Whyte 2000, p.3].

${ }_{16}$ Economic historians, however, have shown that England suffered from a lack of population, while unemployment stemmed from other reasons [Rich 1950, p. 247-248]. 
Christopher Levett explained in 1624, echoing earlier writings of John Smith and Richard Hakluyt, as it would allow "to haue all our idle persons keept to worke and our populous Nation disburthened, and yet to haue them ready to serue our King and Countrey..." [Levett 1624, p. 29]. The 'idleness' caused by unemployment was viewed as almost a deliberate choice and the poor were harshly blamed. Famous explorer John Smith, for example, called such people "vermin" and "drones" [Smith 1616, sig. 94r]. Remarkably, not only the poor, but also wealthy aristocracy and gentry were sometimes accused of idleness in the same context. John Smith, for example, claimed that some nobles were "unworthy of their honours and living" by staying in England, as they were maintaining "idlenesse \& vice". America could be a place for them to make "heroycall deeds of action" like their courageous predecessors [Smith 1616, p. 44]. Finally, another category of people 'suitable' for emigration was comprised of such 'unwanted' elements of society as religious dissenters ${ }^{17}$, vagabonds, beggars, and criminals [Hakluyt 1877, p. 160-161].

Similarly, promotional literature produced a controversial image of a colonist who had already settled in America. Promoters promised that the poor could be "industrious" and "laborous", and the gentry could "abound in honor", once settled in American plantations [Smith 1616, p.44]. However, while discussing numerous failures of the English settlements in America, promoters preferred to put blame on the colonists' idleness and viciousness, than to challenge a good reputation of the lands they had discovered [Levett 1624, p. 26-29]. "I hope none is so malicious, as attribute the fault to the Country nor mee", wrote Smith, accusing the colonists in ill fortunes of Virginia and New England [Smith 1631, p. 31]. Finally, the colonists' image was also ruined by the persistent rumours of the damaging influence of uncivilised American wilderness on Europeans [Greene 1993, p. 32-33].

Thus, contemporary image of an emigrant to America by the 1630s was quite unattractive. It depicted either a person who was an economic or social burden to his mother-country, or a brave and courageous explorer, the latter being closer to the Elizabethan type of a mariner. Contrary to that, migration to Ireland or to the Continent was regarded more positively: a migrant could be a respectful, pious and a family person. Still, on the whole, migration was a common feature of early seventeenth century England. With those differences between the various destinations of migration, the attitudes had also much in common - a desire to tackle one's economic, family, professional or religious problems by moving to another city, country or crossing the ocean.

\section{Discourse of migration to Massachusetts}

In the 1620s, the tensions within England increased. The disputes on taxation, increasing anti-Calvinist politics of Charles I, banishment of popular nonconformist ministers, and economic decline resulted in dissolution of the Parliament in 1629 [Bremer 1995, p. 41-46]. The Englishmen were also deeply alarmed by the results of the Thirty Years' War, especially by the fall of Palatinate and La Rochelle. "Now are these churches become desolate, and may not England?" warned Minister Thomas Hooker before emigrating to

17 For example, John Smith, hesitating that Massachusetts colonists conformed with the Church, added: "if not, it is well they are gone" [Smith 1631, p.2]. For discussion on Separatists, see: [Quinn 1966, p. 362-363]. 
the Netherlands in 1631 [Hooker 1975, p. 233]. The 'vexed and troubled Englishmen'18 reacted to precarious circumstances in different ways: some accepted the situation and conformed to the requirements of the authorities; others tried to improve the state and the Church (as, for example, the 'Feoffees for Impropriations' did $^{19}$ ); and some preferred to leave England ${ }^{20}$. Those who chose the latter course of action faced the same choice as the earlier emigrants: to move to Ireland, to the Continent, or to America ${ }^{21}$. Between 1628 and 1630, several hundred decided to go to New England, thus commencing what would later be called the 'Great Migration'.

Because of the controversies in English society, the discourse of migration from England grew more and more agitated by the end of the 1620s. Emigrants who aimed at settling in America with their families faced a more serious challenge than ever: they had to explain not only the reason for bringing their wives and children so $\mathrm{far}^{22}$, but also the rightfulness of leaving England in such a demanding time. "It will be a great wrong to our Church and Countrie, to take away the good people" was a common objection against emigration [Ryece 1931a, P. 105-106; Winthrop 1931, p. 141]. Therefore, the colonists painstakingly worked to explain and defend their reputation, since a good image of the colony could attract both funding and colonists.

Migration to Massachusetts began in 1628, when a group of investors obtained a land patent from the Council for New England. In the same year, forty colonists moved to Naumkeag (Salem) under the guidance of John Endicott ${ }^{23}$. The following spring, the Massachusetts Bay Company acquired a Royal charter for the colony, and several months later, another three hundred colonists came over to Salem, among them the ministers Francis Higginson and Samuel Skelton. The next wave of migration followed in the spring of 1630, when the colony's Governor John Winthrop and about 700 colonists, including the whole body of the Massachusetts Bay Company, sailed to the colony [Bremer 1995, p. 39-41, 56]. More colonists joined them later in the year, and despite the losses the colony suffered in summer 1630, by 1632 the colony's population comprised approximately 2,000 people [Greene Harrington 2006, p. 12-13] $]^{24}$.

The publicity campaign for Massachusetts was unprecedented for a new-born colony ${ }^{25}$. In autumn of 1629, Francis Higginson's letter with enthusiastic and 'rosy' description of New England arrived from Salem and widely circulated among the 'godly' after-

18 See C. Bridenbaugh on the ordinary people in the Great Migration [Bridenbaugh 1968].

19 'Feoffees for Impropriations' were a group of the 'godly', who tried to procure the benefices for the Puritan clergy by buying the rights to nominate the candidates. They acted from 1613 until 1633, when it was declared illegal. See more: [Bremer 1994, p. 75-81, Puritans 2006, p. 396-398].

20 Still debated is whether it was economics or religion that motivated so many people leave England in the 1630s. Many agree that such a dichotomy is, rather, "a question badly posed", as it is unhistorical to separate one cause from another [Bremer, Foster 1973, p. 201]. See an outline of discussion: [Cressy 2007, p. 75-83, Anderson 1985, p. 340-343].

${ }^{21}$ In the course of the 1630, about 80,000 people moved out of England [Games 2001, p. 4, 234], and only 20,000 of them chose to go to New England [Puritans 2006, p. 408].

22 "To adventure your wholle famylly vpon so many manifeste vncerteynties standeth not with your wysdome and longe experience", Robert Ryece wrote to John Winthrop [Ryece 1931a, p. 106].

${ }^{23}$ In Salem, they joined the small group of the settlers who arrived there in 1623 through the Dorchester Company (organised by John White).

24 To compare, in 1625, only 1,800 colonists lived in Virginia, after eighteen years of existence, less than Massachusetts attracted in four years [Greene Harrington 2006, p. 3].

${ }^{25}$ Even Virginia was not advertised so profoundly at the beginning; another Puritan venture, Providence Island, also lacked such promotion. 
$\operatorname{wards}^{26}$. As the Deputy Governor Thomas Dudley would acknowledge in 1631 (after about 200 colonists died in Massachusetts, including Higginson himself), the authors of the letters "wrote somewhat hyperbolically of many things here" [Dudley 1846, p. 324]. In summer-autumn of 1629, John Winthrop prepared and refined the 'New England tracts' - several explanatory notes in order to explain the reasons and to answer objections against migration [Winthrop 1931b]. The both documents apparently inclined 'godly' to migrate ${ }^{27}$.

After 'Winthrop's fleet' departed from England, promotion expanded, now aiming at a larger audience than the 'godly' circles, as the colonists desperately needed constant funding and support. Four pamphlets were printed in 1630. Among them were Winthrop's short note The Humble request of His Majesties loyall Subjects [Winthrop 1630], John White's extensive pamphlet The Planters' Plea [White 1630] and John Cotton's sermon God's promise to his Plantation [Cotton 1630], all of which put forth reasons for migration. The abovementioned Higginson's description of New England [Higginson 1630] was also published and underwent no less than three editions in a single year. Finally, a list of necessary victual and supplies for the colonists was printed as a broadside [Proportion 1630]. Promotion was not limited to the printed materials, and included manuscript papers and notes of sermons preached (for example, a Model of Christian Charity, delivered by John Winthrop, supposedly, before his departure for America [Winthrop 1931a] ${ }^{28}$ and Thomas Hooker's The Danger of Desertion, delivered in 1631 [Hooker 1975]).

The most striking difference of New England promotion from the earlier promotional literature was that its materials aimed at explaining the lawfulness of leaving England. The 'godly' promoters distinguished between two kinds of law imposed by God on every human: "Perpetuall Law", which applies to everyone and commands an "ordinary" work, and "extraordinary Call", which is given only to a certain community or a nation and commands "extraordinary duty" [White 1630, p. 41-42]. The printed tracts (except Cotton's sermon) interpreted emigration to Massachusetts as an 'ordinary worke' and listed several 'perpetuall warrants' enabling people to move there. The most common of them were: a task given to Adam to "replenish the earth and subdue it" [Winthrop 1931b, p. 139; Cotton 1630, p. 5] and a task given to Apostles to advance "Gods honour" by converting "Gentiles" (Indians) [White 1630, p.13-16].

A more original task was establishing a "true church". Such a service, Winthrop pointed out, was "to be preferred before the betteringe some small parte of a Churche alreadye established", indicating that migrating would be preferable to reforming English or Irish churches [Winthrop 1931b, p. 124-125] ${ }^{29}$. Winthrop believed that establishing a 'true church' in Massachusetts would provide a 'refuge' for those whom God decided to "Saue out of the generall calamity" [Winthrop 1931b, p. 139], for His "Noahs and... Lots" [Hook-

${ }^{26}$ [Higginson 1630]. In the early modern Europe, many letters were initially intended as a public text and circulated among wide groups of people [Hall 2005, p. 32].

27 For example, John Sampson wrote to Winthrop in January 1629 that he decided to send his son to New England "vpon the writinge yow shewed me at your howse..." which was either Higginson's letter or Winthrop's arguments [Winthrop papers 1931, p. 185].

28 The meaning of the sermon may be interpreted differently depending on the audience Winthrop addressed, either only colonists on board of the ship, or the colonists and their friends and kinship who stayed in England. For discussion of the place of delivery of the sermon, see: [Dawson 1991].

${ }^{29}$ In the later draft of this tract Winthrop deleted the words concerning a possibility of "betteringe" an existing Church [Winthrop 1931b, p. 140], probably, trying to prevent accusations of puritanism. 
er 1975, p. 246]. However, many 'godly' considered the task of reforming the Church of England much more important and viewed emigrants as mere cowards who fled "like mice from a crumbling house... prudently looking to their own safety and treacherously giving up the defence of the common cause of the Reformation" 30 .

Promoters of emigration appealed to another 'warrant', which justified moving out of England as a 'calling', or a vocation, which God sets for every man [White 1630, p. 44]. Winthrop, White, and especially Cotton provided hesitant readers with detailed instructions of how to recognise what their 'calling' required [Cotton 1630; Winthrop 1931b, p. 148] ${ }^{31}$. For example, a lack of, or unsatisfactory, employment at home could be interpreted as a 'calling' to migrate. Such arguments depicted emigration not as an expulsion of idle, burdensome people, but as a natural, ordinary following of one's vocation ${ }^{32}$. Thus, contrary to the assumption that emigrants claimed their exceptionality, we may see that they actually were claiming their emigration to have normal, ordinary and unexceptional nature.

However, there were some cases when the 'godly' mentioned that the migration to Massachusetts was 'warranted' by the "extraordinary Call" from God. For example, Winthrop explained that the colonists "entered into Covenant with him [God] for this worke", and got a "speciall Commission" to establish a church [Winthrop 1931a, p. 294-295] ${ }^{33}$. John Cotton also stressed out the special character of Massachusetts migrants, which, being the "Gods people", took the land by God's "promise" (like the Promised Land was given), while the other nations had follow God's providence [Cotton 1630, p.6]. Such statements made some historians think that the 'puritan emigrants' as the 'Gods people' shared a sense of a mission to be performed in American wilderness. However, there is considerable doubt that the sermons delivered in 1630 reflected beliefs in the colony's exceptionalism [Delbanco 1991, p.72-80]. In the seventeenth century England, the phrase 'God's people' never referred to a small group, but implied 'all godly Christians' or more narrowly, the members of the reformed churches. Besides, Winthrop's and Cotton's sermons pursued a practical reason to persuade the listeners to provide better funding and charity for the colony: as the case was "extraordinary, therefore wee must not content our selues with vsuall ordinary meanes", insisted Winthrop [Winthrop 1931b, p. 293]. It is true that the first New England historians like Edward Johnson or Cotton Mather later would depict Winthrop's migration as a holy exodus of the saints ${ }^{34}$. However, until the second half of the 1630s, the sources do not reveal exceptionalist aspirations and show that Massachusetts was generally perceived just as a refuge, and not as the Promised Land ${ }^{35}$.

As the leadership of Massachusetts Bay Company undeniably belonged to the 'godly', the discourse of their migration was even more deeply embedded in the contemporary

\footnotetext{
30 These words are retold by John Cotton. Quoted from: [Bremer 1994, p. 107].

31 The signs of a calling were: the 'outward' call (for example invitation to migrate or lack of employment), the inward feeling, advice of divines, friends, and family.

32 Apparently, this argument was very effective: many Massachusetts colonists confessed afterwards that it was a 'calling' which persuaded them to migrate [Cressy 2007, p. 92-99]

33 The famous phrase about "Citty upon a Hill" refers to a warning that Winthrop made for his listeners: as everyone is looking upon the colonists, so everyone would know of their failure.

34 Cotton Mather called Winthrop "American Nehemiah", thus comparing migration with the exodus from Babel [Mather 1702, p. 8].

${ }^{35}$ In the early 1630s the godly still thought of England as a God's nation, "our Ierusalem" [Cotton 1630, p. 18], but were concerned if God decided to leave her [Hooker 1975].
} 
debates over the issues of the Church and Reformation in England. The promoters of migration tried to persuade people in their loyalty to the Crown and the Church, while the contemporaries were highly suspicious and wondered if it "is secretly harboured faction and separation from the Church" [White 1630, p.59]. These suspicions and replies to them had constituted a considerable part of the discourse of Massachusetts migration.

As mentioned previously, the migrants themselves claimed that one of the reasons to migrate was to help raise and support "a particular Churche" [Winthrop 1931b, p. 140]. Nevertheless, it is still questionable, what kind of "particular Churche" the migrants really had in mind. In the printed pamphlets, the leaders of migration sounded very moderate and declared that the Church of England was their "deare Mother" [Winthrop 1630, p. 3; Cotton 1630, p. 19]. However, the other promotion materials, circulating among the 'godly', were less cautious and offered additional, 'religious' advantages for the migrants to New England. For example, in 1628, just after the patent for the first Massachusetts settlement was obtained, someone, in a manner of Martin Luther, "set up" a letter "on the church of Hamsted [Hempstead?]". The letter declared the reasons why the author and the others had resolved to go to New England, among them the dislike of the church ceremonies and the government [Calendar of State Papers 1859, p. 30]. In April 1630, a minister Charles Chauncey, future president of the Harvard College, was accused of "praise of Puritans" and of saying that some families were going to New England in anticipation of the "changes likely to ensue in church and state" [Calendar of State Papers 1860, p. 233]. Finally, Winthrop himself in his lay sermon insisted that the aim of plantation was to "serue the Lord... vnder the power and purity of his holy Ordinances" [Winthrop 1931a, p.293], which most definitely implied purification of some detested Church practices.

The migrants had to face a more severe charge - that of Separatism (separation from the Church of England), which was condemned not only by the Church, but also by the godly nonconformists. The Massachusetts colonists complained of "false and scandalous reports against us, affirming us to be Brownists ${ }^{36}$ in religion and ill affected to our State at home" [Dudley 1846, p.331]. These reports had some grounds. In 1629, the brothers Brown were banished from Salem and upon their return to England "have raised rumours" that the Salem ministers refused to follow ceremonies and engaged in scandalous preaching [Records 1853, p. 407-408] ${ }^{37}$. Even worse, when the Winthrop fleet arrived in 1630, the Salem church refused to admit them to the sacraments, reasoning that the newcomers did not belong to that particular church. That was totally against the practice of the Church of England and could seem like a separation from it ${ }^{38}$. Upon hearing that, John Cotton wrote an indignant letter to the Salem minister Samuel Skelton, accusing him of being influenced by the 'open' Separatists from New Plymouth [Cotton 1965, p. 482] . $^{39}$. The 'godly' in England were quite concerned and, in retaliation, some of them appear to Browne.

${ }^{36}$ Separatists were sometimes called by the name of one of the earliest adept of Separatism, Richard

37 The General Court of the Company had been dealing with the Browns' complaints and claims for reimbursement for several months [Records 1853, p. 51-54, 60-61, 69].

38 The Church of England is a national church, so its member can take communion with any other member. The refusal to have a communion meant that the Salem church required the membership based on a special 'covenant' - a principle of Congregationalism. Such a requirement was in strict contradiction with the Church of England.

39 Still, a few years later, John Cotton would follow the footsteps of Skelton and will be the minister of a congregational church at Boston. 
have withdrawn their support of the colony. In his 1631 letter to the Countess of Lincoln, Thomas Dudley asked them not to believe in "malicious aspersions" and "be more ready to answer for us than we hear they have been" [Dudley 1846, p. 332 $]^{40}$. Still the suspicions were widely spread. John Smith, for example, in his attempt to defend the reputation of Massachusetts, still failed to conceal his doubts about the conformity of the local churches, observing: "they have Gods true Religion (they say) taught amongst them, the Sabbath day observed, the common Prayer (as I understand) and sermons performed" [Smith 1631, p. 3, 33].

Migration had another religious manifestation in the public discourse - as a means for personal purgation ${ }^{41}$. Many believed that migration to the 'godly' colony might preserve them and their children "from the Common corrupcions of this euill world" [Winthrop 1931a, p. 293] and found confirmations for that in the Bible ${ }^{42}$. Interestingly, the discourse of purgation was also employed by the adversaries of the 'Puritans', who wanted to purge England from the heretics. For example, a satirical ballad Verses on the Puritan Settlement in America, 1631 encouraged Amsterdam and England to get rid of their non-conformists ('fugitives and runagates'), criminals and heretics so that "our church be cleansed and made pure / And keep both herself and state secure" [Quinn 1966, p. 359] ${ }^{43}$. That is an excellent example of how the nonconformists might be seen as a threat not only to the Church of England but also to the state. However, it was not until 1633, when the primary opponent of the 'godly' William Laud became the Archbishop of Canterbury, that we begin to see the migrants claiming themselves to be religious exiles [Games 2001, p.132]. Until then, if they were seeking a refuge, it was only against the "European calamities". In the midst of the European war, the 'godly' argued that if the English Church may fall as the others in Europe, "How woonderfull is the lorde in mercye, that hathe reysed this newe plantation for so comfortable a refuge, for all suche he hathe exempted owte of that general divastation..." [Ryece 1931b, p. 129].

An image of a colonist of Massachusetts also varied from the previous discourse. First, the migrants differed from their predecessors because, as a rule, they travelled in families [Breen, Foster 1973, p. 199], and at least some of them searched for the place to follow the 'pure Ordinancies of God'. The essence of the discourse had also changed: while previously the colonist to America was discussed through the discourse of idleness of the poor and overpopulation, now, as it will be demonstrated below, this image became embedded in the discourse of personal salvation and dignity.

Like their predecessors, the promoters of Massachusetts named overpopulation and unemployment in England as the core reasons to migrate, but their image of the unemployed people was different. The idle people, whom John Smith used to call "drones", were compared by John Cotton to Joseph coming into Egypt, Queen of South traveling to Solo-

${ }^{40}$ Historians generally agree that later, in the course of the 1630s, Massachusetts established congregational churches or 'New England way'. However, the question if congregationalism existed in 1629-1631 is still debatable. For historiography, see: [Khruleva 1994, p. 97-108].

41 The connection of spiritual and physical purgation in early modern religious thought is widely described by Nicholas Terpstra [Terpstra 2016, p. 2, 74-132].

42 John Dane, for example, had decided to go to New England upon finding a verse in Bible, reading "Come out from among them, touch no unclean thing, and I will be your God and you shall be my people". Quoted from: [Fischer 1989, p. 20].

43 In the 1640s, Presbyterians would represent New England as "Gangraena", a breeding ground of heresy [Bremer, Borelho, p. 8]. 
mon, and Paul going to Rome [Cotton 1630, p. 8-9]. Moreover, the promoters insisted that a person could go to the colonies even if he or she was "well placed" at home [Cotton 1630, p. 8]. The reason for that might be the 'calling', but also the lamentable state of England, "the lande abowndeth with murthers, slawghters, Aduleryes, whoredome, drunkennes". In such times, it might be better for a good person to "to make haste owte of Babylon and to seeke to dye rather in the wyldernes...” [Ryece 1931b, p. 129-130].

These arguments apparently aimed not only to persuade godly people to leave England but also to make them choose New England out of other more popular destinations - Ireland, the Netherlands, the West Indies. White stressed that any "well-peopled Countryes" (not only England) used to ripe "couetousnesse, fraud, and violence", and that only moving to the colonies was a suitable "remedy" against these sins [White 1630, p.5]. Ireland seemed to him overpopulated, while the West Indies were regarded unsuitable because of their "rich soyle". White argued that the wealth, which is easily reachable in the Indies, degenerates people, while a country like New England with poorer soil will raise laborious, pious people [White 1630, p. 28, 32-33]. This example shows how the promoters tried to represent the image of a migrant to New England not only as respectful as a migrant to the other countries, but even much better since New England could also offer means for salvation and pious life.

To make an image of a migrant to New England more attractive, promoters accused the preceding unsuccessful American enterprises of selecting inferior colonists. They ("Plantations of Virginia, St. Christophers, Bermudas etc.") proclaimed the necessity to convert Indians, Winthrop wrote, but sent there people unfit for this task [Winthrop 1931b, p. 148]. Similarly, White argued that the colonies were a part of the mother country and therefore they should not be "Emunctories or sinckes of States; to drayne away their filth" [White 1630, p, 33]. Massachusetts not only claimed the necessity of selecting migrants, but actually did it based upon the practical needs for skilled craftsmen in the colony and following recommendations of the ministers about behaviour and godliness of potential migrants. In its instructions to Endicott, the Company's leaders regretted they could not 'purge' the migrants completely ("there may still remain some libertines") and gave freedom to the Governor to punish them or to ship them home [The Company first general letter 1846, p. 157-159]. Therefore, "malicious persons" were regularly sent back to England or had to escape to the neighbouring settlements in America ${ }^{44}$.

Thus, the discourse of lawfulness of migration demonstrated a rehabilitated image of an American colonist. While in the other colonial projects a colonist was regarded as a means for bringing wealth to the state, in New England's promotion a migrant was a person following his or her calling and probably seeking a refuge from sinful world. Such a discourse was constructed for a practical reason: to attract the attention of the 'right' colonists who were more self-conscious, and who preferred to go to a place where economic advantages would be amplified with piety.

Having outlined the discourse of early migration to Massachusetts from the migrants' point of view, we still face a more complicated question: how was this migration regarded in English society?

44 Among them were the brothers Brown, New England famous trouble-maker Thomas Morton [Records 1853, p. 75], "beastly Sodomical boys" and the others. For expulsions from the colony also see: [Shershneva 2002, p.496-497]. 
There are some evidences that this migration was noticed in England, and not only because of its publicity campaign. About 700 men and women joined the Winthrop Fleet in April 1630, and many more joined them later. A significant number of migrants must have impressed at least their relatives and neighbours [Breen, Foster 1973, p. 205, 208]. Besides that, the preparations for departure probably drained (at least were claimed to have drained) the local economy. In May 1630, Lord Mayor of London listed several reasons for "excessive prices of victual at this present" including that "The people which are lately gone for New England and other plantations have carried with them great store of victuals" [Calendar of State Papers 1860, p. 265-266]. The Mayor and Aldermen of Bristol in November 1630 echoed him: "the late furnishing of a ship for New England has in some measure unfurnished their [Devon's and other neighbouring counties'] markets", so that the inhabitants of Bristol "are likely to fall into great distress" [Calendar of State Papers 1860 , p. 384]. However, for the years 1628-1631 we cannot find many mentions of New England migration outside the 'godly community'.

The 'godly' circles also did not have a single opinion on the early migration to Massachusetts. It is true that migration was often discussed as a solution to religious issues, as has been already demonstrated, - as a means of taking refuge in the times of God's wrath, as an attempt to build a "true church", and as a way to purge oneself in seeking salvation. Through this discourse, the Massachusetts promoters extended the polemics over Reformation to the transatlantic English world. Nevertheless, we should not overestimate the impression the migration to Massachusetts had conveyed to the 'godly' community. Some of the most striking evidence to the low importance of the New England project for the contemporary 'godly' is the fact that John Winthrop, as Francis Bremer put it, "a man with limited means and little fame... an obscure Suffolk gentleman" was elected as a Company Governor. There were more suitable Company's supporters, who had political influence, wealth and experience in overseas plantations [Bremer 2003, p. 160-161]. One possible reason why an insignificant Winthrop was preferred was that they viewed Massachusetts as but one of the enterprises they were involved in, and not the most important.

Much more important at the time was another colonising enterprise of the 'godly', also started in 1630 - the Providence Island Colony in the West Indies. It was established by the most prominent 'Puritan grandees', future leaders of the Parliamentary opposition: the Earl of Warwick, John Pym, Lord Saye and Sele, and the others ${ }^{45}$. This colony was located in the middle of the Spanish empire, thus serving as a refuge and as a springboard for attacking the Spaniards and gaining profit. Unlike Massachusetts, Providence Island did not suffer high mortality in its first years, and had a better climate. Due to these facts, from 1630 to 1632 Providence seemed to the 'godly' to be more promising than cold and wild Massachusetts [Kupperman 1993, p.30-34] ${ }^{46}$. Meanwhile, Ireland and the Netherlands still were the most attractive destinations for those seeking for a refuge (Thomas Hooker, William Ames, John Davenport are just a few examples), at least until 1633-1634, when English authorities began rooting out nonconformists from these countries.

45 The earl of Warwick helped to procure the patent and then the Royal charter for New England, thus being involved in the both Puritan enterprises of 1630 .

46 The crucial disadvantage of this colony, however, was that it belonged to the aristocracy, and the land was not granted to the colonists, who were just tenants. The colonists had plantations and slaves, were privateering and attacking the Spanish ships. It collapsed in 1641 after the Spanish conquest [Kupperman 1993]. 
Moreover, despite of the efforts of the promoters, migration to Massachusetts seemed to contemporaries to be a questionable venture. People could well have been discouraged by the rumours brought by the colonies' exiles such as the Browns or Thomas Morton about non-conformism and even separatism allegedly practiced in Massachusetts. Another counter-argument might have been the "ill success" of the other American plantations in the past [Ryece 1931b, p. 130] and present. The news of severe losses Massachusetts suffered in 1630-1631 just added up to the general disappointment in the enterprise [Dudley 1846], even though John Smith tried to recover the image of his beloved New England (not New England colonists!) in his last work [Smith 1631]. Therefore, it is not surprising that the Massachusetts enterprise was seen just as an additional and may be less important in $1628-1631$.

Still, the efforts of promoters of emigration to Massachusetts Bay colony had not been fruitless. To summarise, the attitude toward emigration to America slightly improved within two years. Between 1628 and 1631, the migrants tried to represent their travel as an organic process, typical and natural for any Englishmen, thus making migration to Massachusetts a part of the general English overseas mobility. As such, migration to the Americas was regarded as an extension of the typical English pattern of migration rather than being distinct and different from it. Entrenching the narrative of emigration to America into religious debates brought the two sides of the Atlantic closer and contributed to creation of English Atlantic world. Finally, the image of a migrant was refined. Rather than the adventurers seeking for easy money, the migrants to Massachusetts were represented as industrious and pious people seeking to live in peace with their conscience.

\section{References}

A Proportion of provisions needfvll for svch as intend to plant themselves in New England. London, Fulk and Clifton, 1630, 1 p.

Akimov Y. G. Osnovanie kolonii Novaia Shotlandiia i anglo-frantsuzskoe sopernichestvo v Severnoi Amerike,1621-1632. Amerikanskii ezhegodnik 2000, Moscow, Nauka Publ., 2002, pp. 250-265. (In Russian)

Anderson R. Ch. The Winthrop Fleet: Massachusetts Bay company immigrants to New England, 1629-1630. Boston, New England Historic Genealogical Society Publ., 2012, 912 p.

Anderson V.D. Migrants and Motives: Religion and the Settlement of New England, 1630-1640. The New England Quarterly. 1985, Sep., vol. 58, no. 3, pp. 339-383.

Bailyn B. Atlantic history: Concepts and Contours. Cambridge, Mass., Harvard University Press, 2005, 149 p.

Breen T.H., Foster S. Moving to the New World: The Character of Early Massachusetts Immigration, The William and Mary Quarterly. 1973, Apr., vol. 30, no. 2, pp. 189-222.

Bremer F. J. John Winthrop: America's Forgotten Founding Father. New York, Oxford University Press, 2003, $478 \mathrm{p}$.

Bremer F. J. The Puritan experiment: New England Society from Bradford to Edwards. Hanover and London, University Press of New England, 1995, 255 p.

Bremer F. J., Botelho L. Introduction: Atlantic History and the World of John Winthrop, The World of John Winthrop: Essays on England and New England, 1588-1649. Ed. by F. J.Bremer, L. Botelho. Boston, Massachusetts Historical Society Publ., 2005, pp. 1-21.

Bremer F.J.Congregational Communion: Clerical Friendship in the Anglo-American Puritan Community, 1610-1692. Boston, Northeastern University Press, 1994, 355 p.

Bridenbaugh C. Vexed and Troubled Englishmen, 1590-1642. New York, Oxford University Press, 1968, $487 \mathrm{pp}$.

Calendar of State Papers, Domestic Series, of the Reign of Charles I. 1628-1629. Vol. III. London, Longman, Green, Longman \& Roberts, 1859, 713 p.

Calendar of State Papers, Domestic Series, of the Reign of Charles I. 1629-1631. Vol. IV. London: Longman, Green, Longman \& Roberts, 1860, 680 p.

Cotton J. God's promise to his plantation, as it was delivered in a sermon. London, William Jones, 1630, $20 \mathrm{p}$. 
Cotton J. John Cotton's Letter to Samuel Skelton. Hall D. D. John Cotton's Letter to Samuel Skelton. The William and Mary Quarterly. Third Series. 1965, Jul., vol. 22, no. 3, pp. 478-485.

Cressy D. Coming Over. Migration and Communication between England and New England in the Seventeenth Century. New York, Cambridge University Press, 2007, 324 p.

Dawson H.J.John Winthrop's Rite of Passage: The Origins of the "Christian Charitie" Discourse. Early American Literature. 1991, vol. 26, no. 3, pp. 219-231.

Delbanco A. The Puritan Ordeal. Cambridge, Mass., London, England, Harvard University Press, 1991, $306 \mathrm{p}$.

Dudley to the Countess of Lincoln. Chronicles or the first Planters of the Colony of Massachusetts Bay, from 1623 to 1636. Ed. by A. Young. Boston, Charles C. Little and James Brown, 1846, pp. 301-341.

Fischer D. H. Albion's Seed: Four British Folkways in America. Oxford; New York, Oxford University Press, $1989,946 \mathrm{p}$.

Games A. Migration and the Origins of the English Atlantic World. Cambridge, Mass., and London, Harvard University Press, 2001, 322 p.

Greene E. B., Harrington V. D. American population before the Federal Census of 1790. Baltimore, Genealogical Publishing Co., Inc., 2006, 228 p.

Greene J.P. The Intellectual Construction of America: Exceptionalism and Identity from 1492 to 1800. Chapel Hill, London, The University of North Carolina Press, 1993, 216 p.

Hakluyt R. A Discourse Concerning Western Planting. Ed. by Ch. Deane. Cambridge, Press of J. Wilson and son, $1877,253 \mathrm{p}$.

Hall D. D. Scribal Publication in Seventeenth-Century New England: An Introduction and a Checklist. The Proceedings of the American Antiquarian Society. 2005, Apr., vol. 115, part 1, pp. 29-80.

Higginson F.New-Englands Plantation, Or, a Short and Trve Description of the Commodities and Discommodities of that Countey. $2^{\text {nd }}$ ed. London, T. \&R. Cotes, 1630, n. p.

Hooker T. The Danger of Desertion. Thomas Hooker. The writings in England and Holland, 1626-1633. Eds G. H. Williams, N. Petit, W. Hegret, S. Bush, Jr. Cambridge, Harvard University Press, 1975, pp. 228-252.

Khruleva I. Y. Aktual'nye problemy sovremennoi amerikanskoi istoriografii novoangliiskogo puritanizma. Istoricheskii obraz Ameriki. Moscow, Ladomir Publ., 1994, pp. 97-108. (In Russian)

Kupperman K. O. Providence Island, 1630-1641. The other Puritan Colony. Cambridge, Cambridge University Press, 1993, 393 p.

Mather C. Magnalia Christi Americana: Or the Ecclesiastical History of New-England form its First Planting in the Year 1620 unto the Year of Our Lord, 1698: In 7 Books. Cheapside, Bible and Crowns, 1702. Book 2.

Purchas S. Purchas his Pilgrimage, or relations of the world and the religions observed in all ages and places discovered, from the Creation unto this present: in 4 parts. London, W. Stansby, 1614, 918 p.

Puritans and puritanism in Europe and America: a comprehensive encyclopedia. Ed. by F.J.Bremer and T. Webster. Santa-Barbara, ABC-CLIO, 2006, 695 p.

Quinn D. B. The First Pilgrims. The William and Mary Quarterly. Third Series. 1966, July, vol. 23, no. 3, pp. 359-390.

Records of the Governor and Company of the Massachusetts Bay in New England. Ed. by N. B. Shurtleff. Boston, William White, 1853, Vol. I, 1628-1641. 479 p.

Rich E. E. The Population of Elizabethan England. The Economic History Review. New Series, 1950, vol. 2, no. 3, pp. $247-265$.

Ryece Robert to Winthrop John, Winthrop Papers, in 5 vols. Boston, The Massachusetts Historical Society, The Plimpton Press, 1929-1947. Vol. 2, 1628-1632. 1931a, pp. 105-106.

Ryece Robert to Winthrop John, Winthrop Papers, in 5 vols. Boston, The Massachusetts Historical Society, The Plimpton Press, 1929-1947. Vol. 2, 1628-1632. 1931b, pp. 127-132.

Shershneva S. V. Massachusetskaia teokratiia i Garvardskii kolledzh. Mavrodinskie Chteniia. St. Petersburg, St. Petersburg University Press, 2002, pp. 496-503. (In Russian)

Smith J.A Description of New-England: or the Observations, and Discoveries of Captain John Smith (Admiral of that Country) in the North of America, in the Year of Our Lord 1614. London, H. Lownes, 1616, 62 p.

Smith J.Advertisements for the unexperienced Planters of New-England or any where or, a Path-way to erect a Plantation. London, Iohn Haviland, 1631, 41 p.

Terpstra N. Religious Refugees in the Early Modern World: An Alternative History of Reformation. Cambridge, Cambridge University Press, 2016, 348 p.

The Company's first general letter of instructions to Endicott and his Council. 17 th April, 1629. Chronicles or the first Planters of the Colony of Massachusetts Bay, from 1623 to 1636. Ed. by A. Young. Boston, Charles C. Little and James Brown, 1846, pp. 141-171. 
The Oxford History of the British Empire. Vol. I. The origins of Empire. British Enterprise to the Close of the Seventeenth Century. Ed by N. Canny. Oxford, Oxford University Press, 2001, 533 p.

Thompson R. Mobility and Migration: East Anglian Founders of New England, 1629-1640. Amherst, University of Massachusetts Press, 1994, 305 p.

[White J.] The Planters Plea or The Grounds of Plantations Examined, and usuall Objections Answered. Together with a manifestation of the causes mooving such as have lately undertaken a Plantation in New-England: For the satisfaction of those that question the lawfullnesse of the Action. London, William Jones, 1630, $84 \mathrm{p}$.

Whyte I. D. Migration and society in Britain, 1550-1830. Houndsmills, Basingstoke, Hampshire, England, Macmillan; New York, St. Martin's Press, 2000, 198 p.

Winthrop J. A Model of Christian Charity, in Winthrop Papers, in 5 vols. Boston, The Massachusetts Historical Society, The Plimpton Press, 1929-1947. Vol. 2, 1628-1632. 1931a, pp. 282-295.

Winthrop J. Arguments for the Plantation of New England, in Winthrop Papers, in 5 vols. Boston, The Massachusetts Historical Society, The Plimpton Press, 1929-1947. Vol. 2, 1628-1632. 1931b, pp. 106-149.

Winthrop Papers: in 5 vols. Boston: The Massachusetts Historical Society, The Plimpton Press, 1929-1947. Vol.2, 1628-1632. 1931.

[Winthrop J.] The Hvmble Reqvest of his Maiesties loyall Subjects, the Governour and the Company late gone for New-England. London, Iohn Bellamie, 1630, $10 \mathrm{p}$.

Received: 13.07.2017

Accepted: 20.11.2017 